\title{
RECOMMENDATION OF DIPHTHERIA ANTITOXIN TO DIFFERENT SUSPECTS DURING THE DIPHTHERIA OUTBREAKS,LUMAJANG DISTRICT IN 2018
}

\author{
Munif Arifin \\ Lumajang District Health Office \\ Jalan Jend. S. Parman Number 13 Tel. (0334) 881066, Lumajang, East Java, Indonesia \\ Correspondence Address: Munif Arifin \\ Email: munif.arifin@gmail.com
}

\begin{abstract}
The number of diphtheria suspects in Lumajang district was the second highest in East Java province during the diphtheria outbreaks in 2018. The number of diphtheria cases was more than $500 \%$ in 2018 compared to 2017. To give diphtheria antitoxin (DAT), the provincial diphtheria expert team consider various suspects' characteristics for DAT recommendation as DAT supplies are limited. This case report aimed to explore and describe the relationship between diphtheria suspects' characteristics, including age, gender, symptoms, immunization status, duration of disease, and contact status with other suspects according to the DAT recommendations from the expert team. This case report was descriptive and used a cross-sectional approach. It was conductedduring the diphtheria outbreaks and involved total samples of all suspects. Based on age, the majority of the suspects (92\%)were under 19 years old. Suspects at this age were the target of an outbreak response immunization (ORI) program. Those who were not targetted to receive ORI (aged over 19 years) began to appear in November and mostly in December. The trend of non-ORI targetted age increased after the third round of ORI implementation. According to the report form parents, most suspects $(46.7 \%)$ had complete immunization status, and only $6.7 \%$ of their immunization records were reported on growth chart cards. All suspects with positive diphtheria never had and know routine immunization records. The laboratory tests show only $5 \%$ were suspected with positive diphtheria with a cultural type of mitis toxigenic. As many as $32 \%$ of the total suspects were recommended for DAT treatment. The use of controlled DAT could save 1,640,000 iU.
\end{abstract}

Keywords: Diphtheria, outbreak response immunization, diphtheria antitoxin.

\begin{abstract}
ABSTRAK
Jumlah suspek penyakit difteri di Kabupaten Lumajang tertinggi ke dua di Jawa Timur saat Kejadian Luar Biasa (KLB) difteri tahun 2018. Terjadi peningkatan kasus pada tahun 2018 mencapai lebih 500\% dibandingkan tahun 2017. Untuk memberikan serum antidifteri pada suspek, Tim Ahli Difteri Provinsi mempertimbangkan berbagai karakteristik suspek untuk rekomendasi serum antidifteri. Rekomendasi ini dilakukan karena keterbatasan persediaan serum antidifteri. Case report bertujuan untuk mengeksplorasi dan mendiskripsikan hubungan karakteristik suspek difteri, meliputi umur, jenis kelamin, gejala, status imunisasi, lama sakit, dan status kontak dengan suspek lain dengan rekomendasi serum antidifteri dari tim ahli. Case report ini menggunakan rancangan diskriptif dan pendekatan potong lintang. Case report ini dilakukan selama KLB difteri dan melibatkan total sampel seluruh suspek. Berdasarkan usia, mayoritas suspek (92\%) berusia di bawah 19 tahun. Usia ini merupakan sasaran program imunisasi tanggap kejadian luar biasa. Suspek yang bukan sasaran program imunisasi ini (berumur lebih dari 19 tahun) mulai muncul pada bulan Nopember dan sebagian besar pada bulan Desember. Tren usia suspek yang bukan sasaran ORI meningkat setelah pelaksanaan ORI putaran ke tiga. Sebagian besar suspek (46.7\%) mempunyai status imunisasi lengkap berdasarkan informasi dari orang tua, dan hanya $6.7 \%$ mempunyai catatan imunisasi pada Kartu Menuju Sehat (KMS). Seluruh suspek dengan positif difteri tidak pernah melakukan dan tidak mengetahui catatan imunisasi rutin tersebut. Uji laboratorium menunjukkan hanya terdapat $5 \%$ suspek dengan hasil uji laboratorium positif mitis toksigenik. Jumlah suspek yang direkomendasikan mendapatkan terapi serum antidifteri sebanyak 32\%. Penggunaan serum antidifteri yang "terkendali" dapat menghemat 1.640.000 iu serum antidifteri.
\end{abstract}

Kata Kunci: Difteri, imunisasi tanggap kejadian luar biasa, serum antidifteri.

\section{INTRODUCTION}

Diphtheria is a highly contagious disease that can be prevented by giving immunization to suspects. This disease is caused by the gram-positive bacterium Corynebacterium diphtheria strain of the toxin and characterized by inflammation on 
the infected parts, especially the mucous membranes of the pharynx, larynx, tonsils, nose, and skin. Severe diphtheria can be characterized by difficulty in swallowing, shortness of breath, stridor, and neck swelling that looks like a bull neck. Death usually occurs due to obstruction or blockage of the airway, damage on the heart muscle, and abnormalities in the central nervous system and kidney (Indonesian Ministry of Health, 2017).

The Circular Letter of the Governor of East Java Number 460/69/012.4/2018 concerning determination of diphtheria outbreaks in East Java and the Decree of the Regent of Lumajang district Number 188.45/16/427.12/2018 concerning diphtheria outbreaks announced that diphtheria outbreaks occurred in Lumajang district, as well as other East Java regions. Outbreaks of infectious diseases, especially those that can be prevented by immunization become public health problems because they result in greater risks of morbidity and deaths. The disease transmission should be anticipated and prevented quickly and accordingly.

During the diphtheria outbreaks, an outbreak response immunization (ORI) program was carried out through the distribution of 3 doses of diphtheria immunization to people aged 1-19 years. This program has also been carried out in regions where such outbreaks occur as stipulated in the Regulation of Indonesian Ministry of Health No. 1501 of 2010 concerning certain types of communicable diseases that need plague and mitigation measures.

The number of diphtheria suspects in Lumajang district in 2018 was ranked the second highest in East Java province. In 2017, there were 11 diphtheria suspects and 60 suspects in 2018. The increase between the years was more than $500 \%$. Such increase occurred possibly as the primary healthcare center and hospital surveillance officers did track and report the suspects quickly. Some signs and symptoms of diphtheria were still unclear, but some people who had such obscure symptoms such as painful swallowing, pseudomembrane, epistaxis, bull neck, and stridor had been reported as suspects. Fast case tracking could give fast prevention measures for the disease transmission, leaving aside the possibility of overdiagnosis (Lumajang District Health Office, 2018).

According to the standard operating procedure (SOP), suspects found in less than 24 hours must be reported to the East Java Provincial Health Office in Form Dip 1 , which contains various suspects' data, including name, age, address, immunization status, signs and symptoms, and others. This report is used not only as an outbreak epidemiological update but also as considerations for the Diphtheria Expert Team of East Java Province to recommend DAT treatment for the suspects. The expert team come from Dr. Soetomo District General Hospital and Universitas Airlangga The team sent the recommendation along with the suspects' pseudomembrane photos through WhatsApp chats.

Not all suspects receive DAT treatment due to the limitations of DAT at the provincial level. Hence, DAT was distributed by recommendationtreatment that applied to diphtheria suspects in Lumajang district. Treatment

\section{METHODS}

This case report used a quantitative-descriptive design and a cross-sectional approach during the 2018 diphtheria outbreaks. It sampled all diphtheria suspects in Lumajang district and focused on the analysis of DAT treatment recommendations of the provincial diphtheria expert team. The mechanism of DAT recommendation was done at some stages. First, every diphtheria suspect found in a health 
service facility (primary healthcare center, clinic, or hospital) was reported online through WhatsApp to the East Java Provincial Health Office. The report consisted of suspects' pseudomembrane photos, immunization status, age, gender, age, symptoms (pseudomembrane, epistaxis, bull neck, and stridor), date of disease, history of contact with other suspects, treatment given, or bleeding status during a throat or nasal swab. Second, the provincial diphtheria expert team provided several possible recommendations based on the report: 1 ) Negative diphtheria, 2) Erythromycin antibiotic treatment, PPC, or mouth rinse, and 3) DAT treatment (with its dosage). In the third stage, the epidemiological surveillance officers tracked the suspects and people in close contact with them and collected a specimen collection of the throat and nasal swabs, as well as prophylaxis. Furthermore, the swab results were tested for further diagnosis in the Central Laboratory of Health Laboratory of Surabaya .

This case report basically identified the relationship between DAT recommendationtreatmentas an independent variable and dependent variables including immunization status, age, gender, symptoms (pseudomembranous, epistaxis, bull neck, stridor), date of disease, and history of contact with other suspects. Meanwhile, to see the significance and degree of the relationship, this case report utilized the bivariate test. Further, multivariate logistic regression was carried out to analyze statistically significant risk factors for DAT recommendation.

\section{RESULTS}

During the diphtheria outbreaks, the suspects aged 1-19 years were given 3 doses of diphtheria immunization in February, July, and November 2018. This immunization program was according to the
Letter of Director-General of P2P Number UM.01.05/1/3274/2017 on $21^{\text {st }}$ December 2017 concerning about the prevention of diphtheria outbreaks.

Moreover, the East Java Provincial Government issued the Letter of East Java Governor to the Regent/Mayor on $8^{\text {th }}$ January 2017 Number: 460/69/012.4/2018, regarding determination of diphtheria outbreaks, anticipation of surges and disease transmission, and the implementation of an outbreak response immunization (ORI) program.

The immunization program was carried out in regions where the outbreaks occurred based on the Regulation of Indonesian Ministry of Health No. 1501 of 2010 concerning certain types of communicable diseases that need plague and mitigation measures. This program aims to break the chain of transmission and immediately end the outbreaks and high immunity gaps in infants. Few infants in Lumajang have received complete basic immunization, and this immunization has not equally been distributed. Ideally, further immunization should be given to children at school ages to future outbreaks.

\section{The number of diphtheri suspects in Lumajang district in 2018}

The number of diphtheria suspects in 2018 was 60 suspects spread in 22 primary healthcare centers, except Ranuyoso, Pronojiwo, and Penanggal Primary Healthcare Centers.

Suspects' characteristics based on domicileThe suspects' domiciles are presented in Table 1.

Table 1. Frequency Distribution of the Diphtheria Suspects based on Domiciles in Lumajang District in 2018.

\begin{tabular}{lcc}
\hline \multicolumn{1}{c}{ Puskesmas } & Total & $\boldsymbol{\%}$ \\
\hline Rogotrunan & 17 & 27.87 \\
\hline Pasirian & 6 & 9.84 \\
\hline Kedungjajang & 5 & 8.20 \\
\hline Sukodono & 5 & 8.20 \\
\hline
\end{tabular}




\begin{tabular}{lcc}
\hline \multicolumn{1}{c}{ Puskesmas } & Total & \% \\
\hline Candipuro & 3 & 4.92 \\
\hline Jatiroto & 3 & 4.92 \\
\hline Padang & 2 & 3.28 \\
\hline Randuagung & 2 & 3.28 \\
\hline Tempursari & 2 & 3.28 \\
\hline Tunjung & 2 & 3.28 \\
\hline Yosowilangun & 2 & 3.28 \\
\hline Bades & 1 & 1.64 \\
\hline Gesang & 1 & 1.64 \\
\hline Bades & 1 & 1.64 \\
\hline Gesang & 1 & 1.64 \\
\hline Gucialit & 1 & 1.64 \\
\hline Klakah & 1 & 1.64 \\
\hline Kunir & 1 & 1.64 \\
\hline Labruk & 1 & 1.64 \\
\hline Pasrujambe & 1 & 1.64 \\
\hline Senduro & 1 & 1.64 \\
\hline Sumbersari & 1 & 1.64 \\
\hline Tekung & 1 & 1.64 \\
\hline Tempeh & 1 & 1.64 \\
\hline Total & $\mathbf{6 0}$ & $\mathbf{1 0 0}$ \\
\hline & 1 & 1 \\
\hline
\end{tabular}

Most of the suspects (28\%) lived in the working area of the Rogotrunan Primary Healthcare Center, but the suspects spread in almost all working areas $(88 \%)$.

Based on monthly trends, diphtheria suspect fluctuations are presented in Graph 1.

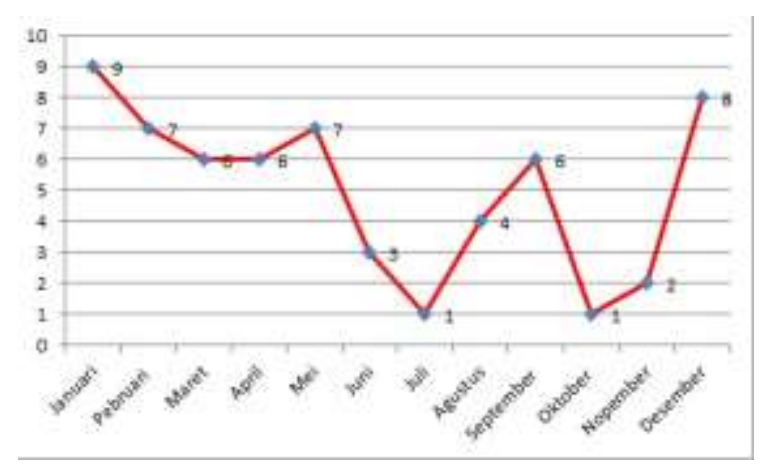

Graph 1. Trends of Diphtheria Suspects in Lumajang District in 2018.

At the beginning of the year from January to July, the trend of suspects tended to fall, then rose in July to September, and significantly increased again in December. Table 2 illustrates
Table 2. Distribution of Suspects' Characteristics based on Age and Gender in Lumajang District in 2018.

\begin{tabular}{lcc}
\hline $\begin{array}{c}\text { Suspects' } \\
\text { Characteristics }\end{array}$ & n & $\%$ \\
\hline Age & & \\
$\quad<1$ year & & \\
$>1$ s/d 2 year & 1 & 1.7 \\
>2 s/d 8 year & 5 & 8.3 \\
> 8 year & 46 & 76.7 \\
& 8 & 13.3 \\
\hline Gender & & \\
$\quad$ Male & 37 & 60.7 \\
Female & 23 & 37.7 \\
\hline
\end{tabular}

The majority of the suspects $(76.7 \%)$ were aged 2-8 years old. The lowest age of suspicion is 1 year, the highest is 39 years. Based on gender, most of the suspects were male $(60.7 \%)$, while women were $37.7 \%$.

\section{Suspects' characteristics based on risk factors for immunization status and history of contact}

This case report presents risk factors for immunization status and history of contact in Table 3.

Table 3. Frequency Distribution of Risk Factors for Immunization Status and History of Contacts with Other Diphtheria Suspects in Lumajang District in 2018.

\begin{tabular}{lll}
\hline \multicolumn{1}{c}{ Variables } & n & \% \\
\hline $\begin{array}{l}\text { Immunization } \\
\text { Status }\end{array}$ & & \\
$-\quad \begin{array}{l}\text { Complete } \\
\text { Growth Chart } \\
\text { Cards }\end{array}$ & 4 & 6.7 \\
$-\quad \begin{array}{l}\text { Information } \\
\text { from parents }\end{array}$ & 2 & 46.7 \\
$-\begin{array}{l}\text { Incomplete } \\
\text { records }\end{array}$ & 8 & 11.7 \\
\end{tabular}




\begin{tabular}{|c|c|c|}
\hline Variables & $\mathbf{n}$ & $\%$ \\
\hline 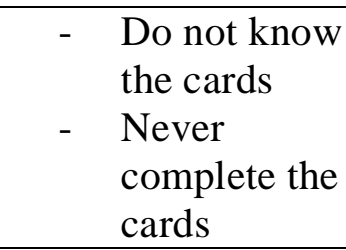 & $\begin{array}{l}9 \\
1 \\
2\end{array}$ & $\begin{array}{l}15.0 \\
20.0\end{array}$ \\
\hline $\begin{array}{l}\text { History of contact } \\
-\quad \text { Never } \\
-\quad \text { Ever }\end{array}$ & & \\
\hline & $\begin{array}{l}5 \\
5 \\
5\end{array}$ & $\begin{array}{c}91.7 \\
8.3\end{array}$ \\
\hline
\end{tabular}

Based on immunization status, most of the suspects $(46.7 \%)$ had complete immunization as their parentas told. Only $6.7 \%$ had complete immunization reported in their growth chart cards.Regarding a history of contact, 55 suspects $(91.7 \%)$ had never been in contact with other suspects, while 5 others $(8.3 \%)$ had.

\section{Suspects' characteristics based on symptoms}

Table 4 explains that all suspects $(100 \%)$ were positive pseudomembranous, 58 suspects $(96.7 \%)$ were negative epistaxis, 41 suspects $(68.3 \%)$ had no symptoms of bull neck, and 38 suspects $(63.3 \%)$ had no symptoms of stridor.
Further symptoms were presented in Table 4.

Table 4. Frequency Distribution of Suspects' Diphtheria Symptoms in Lumajang District in 2018.

\begin{tabular}{ccc}
\hline $\begin{array}{c}\text { Suspect } \\
\text { Characteristics }\end{array}$ & n & $\%$ \\
\hline $\begin{array}{c}\text { Pseudomembranous } \\
\text { - Negative }\end{array}$ & & \\
- Positive & 0 & 0 \\
& 60 & 100 \\
& & \\
\hline Epistaxis & & \\
- Negative & 58 & 96.7 \\
- Positive & 2 & 3.3 \\
$\quad$ & & \\
\hline Bull neck & & \\
- Negative & 41 & 68.3 \\
- Positive & 19 & 31.7 \\
$\quad$ Stridor & & \\
- Negative & 38 & 63.3 \\
- Positive & 22 & 36.7 \\
\hline
\end{tabular}

Suspect characteristics based on the duration of disease

Table 5 presents how long the suspects suffered from diphtheria before being treated in health service facilities.

Table 5. Frequency Distribution of the Duration of Disease Experienced by the Diphtheria Suspects in Lumajang District in 2018.

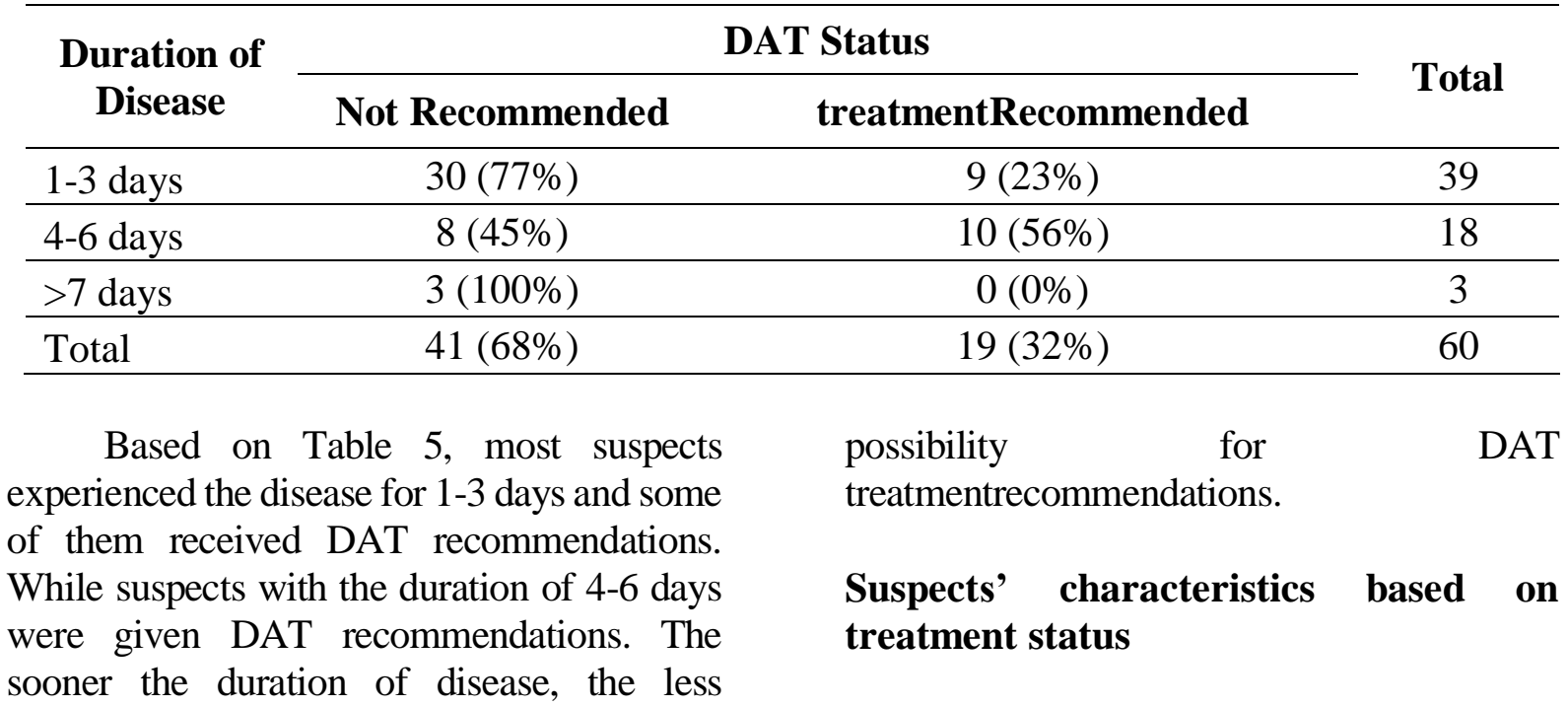


Besides, this case report shows that 55 suspects $(91.7 \%)$ were hospitalized, and 5 other suspects $(8.3 \%)$ received outpatient care. Before being hospitalized, 39 suspects (65\%) had been sick for 1-3 days, 18 suspects had suffered from the disease for 4-6 days $(30.0 \%)$, and 3 suspects had been sick for 7 days $(5 \%)$.

Table 6. Frequency Distribution of Treatment Status of Diphtheria Suspects in Lumajang District in 2018.

\begin{tabular}{|c|c|c|}
\hline Variables & $\mathbf{n}$ & $\%$ \\
\hline \multicolumn{3}{|l|}{ Treatment status } \\
\hline - Inpatient & 55 & 91.7 \\
\hline - Outpatient & 5 & 8.3 \\
\hline \multicolumn{3}{|l|}{ Duration of Disease } \\
\hline - 1-3 days & & \\
\hline - $\quad$ 4-6 days & & \\
\hline - $\quad>7$ days & & \\
\hline & 39 & 65.0 \\
\hline & 18 & 30.0 \\
\hline & 3 & 5.0 \\
\hline
\end{tabular}

\section{Suspects' characteristics based on DAT} status

In Table 7, this study finds 41 suspects $(68.3 \%)$ were not given DAT treatment, while $19(31.7 \%)$ others were given DAT treatment. Regarding DAT dose, of 19 suspects given DAT treatment, 12 suspects $(20 \%)$ received a DAT dose of 40,000 Iu, 4 suspects received a DAT dose of 20,000 Iu, 2 suspects had a DAT dose of $60,000 \mathrm{Iu}$, and 1 suspect received a DAT dose of $80,000 \mathrm{Iu}$.

Table 7. Frequency Distribution of DAT Status in Diphtheria Suspects in Lumajang District in 2018.

\begin{tabular}{lcc}
\hline \multicolumn{1}{c}{ Variables } & $\mathbf{n}$ & $\%$ \\
\hline $\begin{array}{l}\text { Diphtheria Antitoxin } \\
\text { (DAT) }\end{array}$ & & \\
$\quad$ Not & & \\
$\quad$ recommended & 41 & 68.331 .7 \\
- Recommended & 19 & \\
\hline DAT dose & & \\
$\quad$ Not recommended & & \\
20.OOO IU & 41 & 68.33 \\
40.OOO IU & 4 & 6.67 \\
60.000 IU & 12 & 20.00 \\
80.000 IU & 2 & 3.33 \\
Total & 1 & 1.67 \\
& 60 & 100.00 \\
\hline
\end{tabular}

DAT given to suspects was associated with duration of disease prior to health treatment at health service facilities.

Table 8. Frequency Distribution of DAT Recommendation and Duration of Disease in Diphtheria Suspects in Lumajang District in 2018.

\begin{tabular}{|c|c|c|c|c|}
\hline \multirow{2}{*}{\multicolumn{2}{|c|}{$\begin{array}{l}\text { Duration of } \\
\text { Disease }\end{array}$}} & \multicolumn{3}{|c|}{ DAT Status } \\
\hline & & Not Recommended & treatmentRecommended & Total \\
\hline $\begin{array}{l}1-3 \\
\text { days }\end{array}$ & Count & 30 & 9 & 39 \\
\hline & $\%$ within & $77 \%$ & $23 \%$ & $100 \%$ \\
\hline & $\%$ of Total & $50 \%$ & $15 \%$ & $65 \%$ \\
\hline $\begin{array}{l}4-6 \\
\text { days }\end{array}$ & Count & 8 & 10 & 18 \\
\hline & $\%$ within & $44 \%$ & $56 \%$ & $100 \%$ \\
\hline & $\%$ of Total & $13 \%$ & $17 \%$ & $30 \%$ \\
\hline $\begin{array}{l}>7 \\
\text { days }\end{array}$ & Count & 3 & 0 & 3 \\
\hline
\end{tabular}




\begin{tabular}{lrrrr}
\hline $\begin{array}{l}\text { Duration of } \\
\text { Disease }\end{array}$ & Not Recommended & DAT Status & \\
\cline { 3 - 6 } & \% within & $100 \%$ & $0 \%$ & $100 \%$ \\
\hline & $\%$ of Total & $5 \%$ & $0 \%$ & $5 \%$ \\
\hline Total & Count & 41 & $32 \%$ & $100 \%$ \\
\hline & $\%$ within & $68 \%$ & $32 \%$ & $100 \%$ \\
\hline & $\%$ of Total & $68 \%$ & & 0 \\
\hline
\end{tabular}

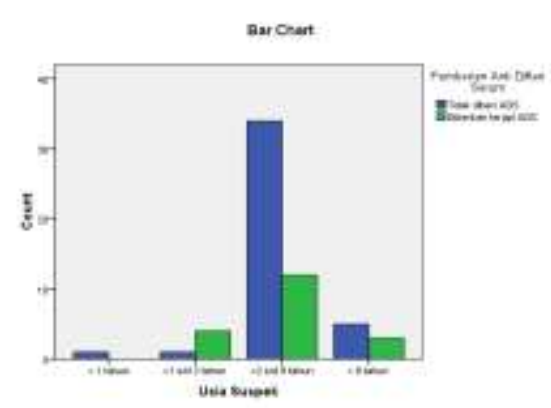

Graph 2. Percentage of Suspects' Age and DAT Recommendation in Lumajang District 2018.

Graph 2 shows that the majority of DAT recommendations were given to suspects aged 2-8 years. However, most suspects aged 1-2 years were not recommended for DAT. treatment

Suspects' characteristics based on laboratory test results

Based on Table 9, there were 3 suspects $(5 \%)$ with the positive of toxigenic mythic.
Table 9. Frequency Distribution of Laboratory Test Results of Diphtheria Suspects in Lumajang District in 2018.

\begin{tabular}{lccc}
\hline \multirow{2}{*}{ DAT Status } & \multicolumn{3}{c}{$\begin{array}{c}\text { Results of laboratory } \\
\text { specimen examination }\end{array}$} \\
\cline { 2 - 4 } & Negative & Positive & Total \\
\hline $\begin{array}{l}\text { Not } \\
\text { Recommended }\end{array}$ & $\begin{array}{c}40 \\
(98 \%)\end{array}$ & $1(2 \%)$ & $\begin{array}{c}41 \\
(100 \%)\end{array}$ \\
\hline $\begin{array}{l}\text { Recommended } \\
\text { treatment }\end{array}$ & 17 & $2(10 \%)$ & 19 \\
\hline Total & $50 \%)$ & & $(100 \%)$ \\
\hline
\end{tabular}

The implementation of outbreak response immunization (ORI) program in 2018

The outbreak response immunization (ORI) in Lumajang district was conducted in 3 rounds, between February-March, June-July, and November-December 2018. Table 10 shows the recapitulation of ORI coverage in Lumajang district in 2018.

Table 10. Coverage of ORI in Lumajang District 2018.

\begin{tabular}{|c|c|c|c|c|c|c|c|c|c|c|c|}
\hline \multirow[b]{3}{*}{$\begin{array}{c}\text { Age } \\
\text { Range }\end{array}$} & \multirow{2}{*}{\multicolumn{2}{|c|}{ Total target }} & \multicolumn{9}{|c|}{ Total coverage of 1 to $<19$ years } \\
\hline & & & \multicolumn{3}{|c|}{ Round 1} & \multicolumn{3}{|c|}{ Round 2} & \multicolumn{3}{|c|}{ Round 3} \\
\hline & Proy & Riil & Abs & $\begin{array}{c}\text { Pro } \\
\mathbf{y} \\
(\%)\end{array}$ & $\begin{array}{c}\text { Rii } \\
\mathbf{l} \\
(\% \\
)\end{array}$ & Abs & $\begin{array}{c}\text { Pro } \\
\mathbf{y} \\
(\boldsymbol{\%})\end{array}$ & $\begin{array}{l}\text { Riil } \\
(\%)\end{array}$ & Abs & $\begin{array}{c}\text { Pro } \\
\text { yi } \\
(\%)\end{array}$ & $\begin{array}{l}\text { Riil } \\
(\%)\end{array}$ \\
\hline $\begin{array}{l}1 \mathrm{~S} / \mathrm{D}< \\
5 \text { Years }\end{array}$ & $\begin{array}{c}57.71 \\
7\end{array}$ & 59.841 & $\begin{array}{c}58.47 \\
1\end{array}$ & 101 & 98 & $\begin{array}{c}58.47 \\
1\end{array}$ & 101 & 98 & $\begin{array}{c}56.56 \\
3\end{array}$ & $\begin{array}{c}98.0 \\
0\end{array}$ & 95 \\
\hline $\begin{array}{l}\geq 5-<7 \\
\text { Years }\end{array}$ & $\begin{array}{c}30.09 \\
9\end{array}$ & 40.771 & $\begin{array}{c}40.87 \\
1\end{array}$ & 136 & $\begin{array}{c}10 \\
0\end{array}$ & $\begin{array}{c}39.80 \\
5\end{array}$ & 132 & 98 & $\begin{array}{c}39.95 \\
1\end{array}$ & $\begin{array}{c}132 . \\
73\end{array}$ & 98 \\
\hline
\end{tabular}




\begin{tabular}{|c|c|c|c|c|c|c|c|c|c|c|c|}
\hline \multirow{3}{*}{$\begin{array}{c}\text { Age } \\
\text { Range }\end{array}$} & \multirow{2}{*}{\multicolumn{2}{|c|}{ Total target }} & \multicolumn{9}{|c|}{ Total coverage of 1 to $<19$ years } \\
\hline & & & \multicolumn{3}{|c|}{ Round 1} & \multicolumn{3}{|c|}{ Round 2} & \multicolumn{3}{|c|}{ Round 3} \\
\hline & Proy & Riil & Abs & $\begin{array}{c}\text { Pro } \\
\mathbf{y} \\
(\%)\end{array}$ & $\begin{array}{c}\text { Rii } \\
1 \\
(\% \\
)\end{array}$ & Abs & $\begin{array}{c}\text { Pro } \\
\mathbf{y} \\
(\%)\end{array}$ & $\begin{array}{l}\text { Riil } \\
(\%)\end{array}$ & Abs & $\begin{array}{c}\text { Pro } \\
\text { yi } \\
(\%)\end{array}$ & $\begin{array}{l}\text { Riil } \\
(\%)\end{array}$ \\
\hline $\begin{array}{c}\geq 7-<19 \\
\text { Years }\end{array}$ & $\begin{array}{c}185.6 \\
60\end{array}$ & $\begin{array}{c}160.91 \\
9\end{array}$ & $\begin{array}{c}158.0 \\
14\end{array}$ & 85 & 98 & $\begin{array}{c}157.6 \\
28\end{array}$ & 85 & 96 & $\begin{array}{c}156.7 \\
34\end{array}$ & $\begin{array}{c}84.4 \\
2\end{array}$ & 97 \\
\hline $\begin{array}{l}\text { Total } \\
1-<19 \\
\text { Years }\end{array}$ & $\begin{array}{c}273.4 \\
76\end{array}$ & $\begin{array}{c}261.53 \\
1\end{array}$ & $\begin{array}{c}256.7 \\
55\end{array}$ & 94 & 98 & $\begin{array}{c}255.9 \\
04\end{array}$ & 94 & 98 & $\begin{array}{c}253.2 \\
48\end{array}$ & $\begin{array}{c}92.6 \\
0\end{array}$ & 97 \\
\hline
\end{tabular}

Overall, the ORI coverage had reached the minimum target of $90 \%$. The trends show a decrease in ORI coverage in the third round.

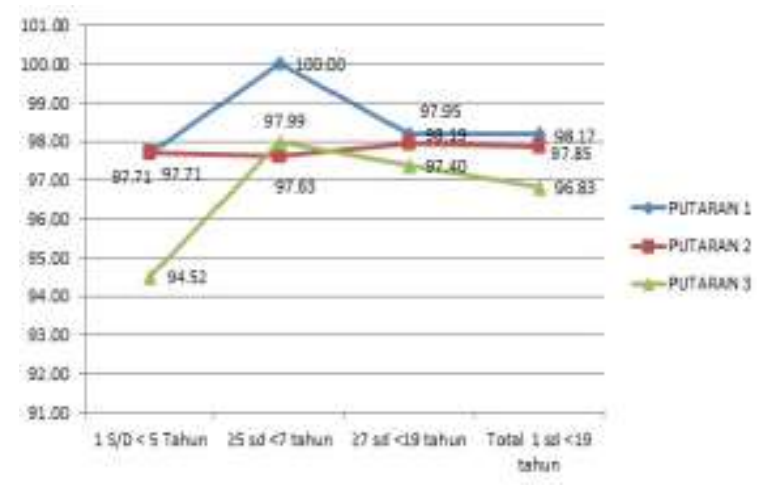

Graph 3. ORI Coverage in Lumajang District in 2018.

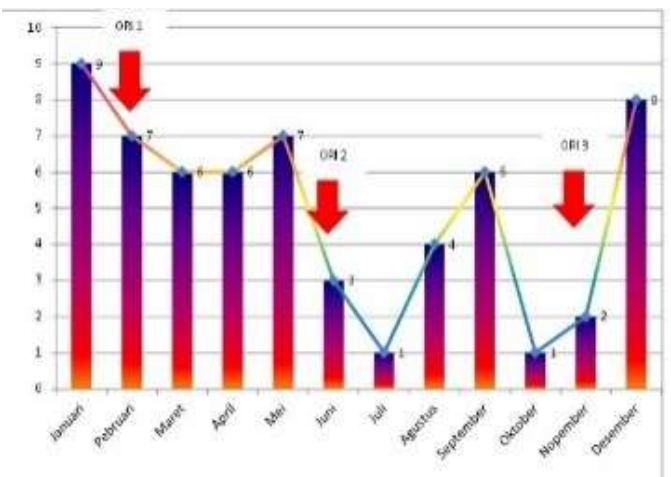

Graph 4. ORI Coverage and the Number of Diphtheria Suspects in Lumajang District in 2018.

Graph 3 illustrates the trend in round 3 was the most decreasing ORI coverage, especially of the target age of 1 to $<5$ years. The coverage corresponds to the number of diphtheria suspects in Lumajang district as seen in Graph 4. The number of diphtheria suspects decreased while the ORI coverage increased. Meanwhile, Graph 5 shows the coverage of the target age of ORI program.

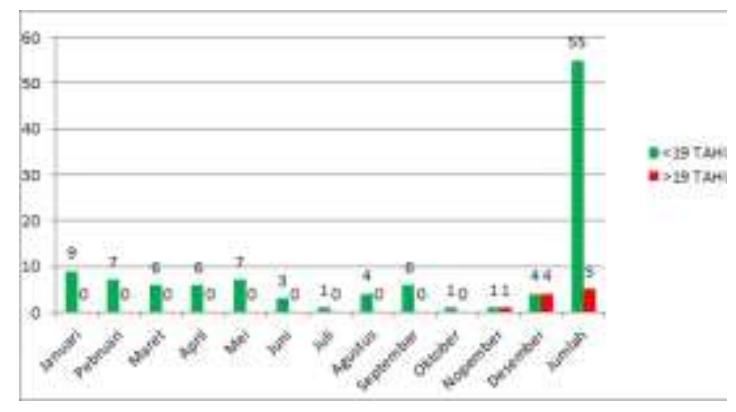

Graph 5. The Target Age of Diphtheria Suspects for ORI Program in Lumajang District in 2018.

The number of non-targetted age for ORI program began to emerge in November, and the highest one was found in December. The calculation of the association between routine immunization and suspects' characteristics is available in Graph 6. 


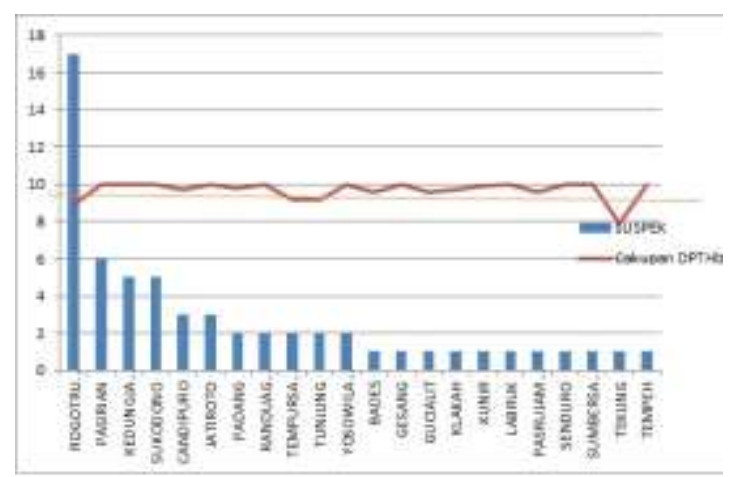

Graph 6. Association between Diphtheria Suspects and Routine Immunization Coverage in Lumajang District in 2018.

Graph 6 illustrates only Rogotrunan Primary Healthcare Center had below 95\% of routine immunization coverage, but it had the highest number of suspects. Whereas Tekung Primary Healthcare Center had lower coverage and a low number of suspects.

\section{DISCUSSION}

This study reports an increase in sdiphtheria suspects occurred during the diphtheria outbreaks in Lumajang district. In 2017, there were 11 diphtheria suspects, while in 2018 there were 60 suspects. Based on the results of laboratory tests, 3 suspects were positive toxigenic mythic. The number of diphtheria suspects in 2018 was higher than in 2017. In 2018, the suspects were found in almost all regions $(88 \%$ working areas of primary healthcare centers).

According to the standard operating procedure (SOP) and diphtheria prevention technical guidelines, diphtheria situation would be considered an outbreak if one suspect was found without waiting for laboratory test results. Immediate countermeasures were done, such as taking all specimens of the throat and nasal swabs. The specimens were then investigated in the Central Laboratory of Health Laboratory (BBLK) of Surabaya. During the countermeasures, treatments were given and did have the success rate of $100 \%$, and there were no deaths as $100 \%$ suspects were treated less than 24 hours according to the standard.

\section{Epidemiological aspects of diphtheria suspicion}

Most of the suspects (28\%) lived in the working areas of Rogotrunan Primary Healthcare Center. While there were eight suspects from the Pasirian Primary Healthcare Center, five others from Kedungjajang Primary Healthcare Center, five others from Sukodono Primary Healthcare Center, 3 suspects from Candipuro Primary Healthcare Center, and 3 suspects from Jatiroto Primary Healthcare Center. While there was only one suspect in each of other primary healthcare centers. The other three primary healthcare centers (Pronojiwo, Penanggal, and Ranuyoso) had no diphtheria suspects in 2018.

Some primary healthcare centers with the high number of diphtheria suspects were located in urban areas (Rogotrunan, Sukodono, and Kedungjajang Primary Healthcare Centers), or in areas with high population density (Pasirian and Jatiroto Primary Healthcare Centers). Whereas no diphtheria suspects wre found in highland areas (Pronojiwo, Penanggal, and Ranuyoso). Further study is required to examine the relationship between topographic and environmental aspects and diphtheria suspicion.

\section{Suspects' characteristics based on age and gender}

After the first ORI round and the second ORI round, the number of diphtheria suspects fluctuated. In 2018, only 5 suspected people were aged over 19 years (non-targetted age for ORI), 4 suspects were found in December, and 1 suspect was found in November. This shows that the shifting trend of non-targetted suspects occurred after the implementation of the third ORI round.

From January to October 2018, there were no suspected people aged 19 years in the first and second ORI rounds. After these 
roundsa, suspects aged over 19 years old were discovered in November (1 suspect) and December (4 suspects). It can be assumed that after of the first and second ORI rounds, the suspects receiving ORI had stronger immunity, and the non-targetted suspects' age for ORI had replaced the targeted suspects' age. The chi-square test shows a significant relationship between ORI and the shifting age of diphtheria suspects with a $\alpha$ value of 0.004 .

\section{Suspects' characteristics based on risk factors for immunization status and history of contact}

Regarding history of contact with other suspects, , 4 of 5 suspects $(80 \%)$ who ever had contact with other suspects were aged 5 years, and 1 suspect with similar contant was 3 years old. It suggests that childhood or younger ages are the state of playtime which greatly leads children to contract diphtheria.

The majority of the suspects $(75 \%)$ were over 5 years old, and only $25 \%$ of them were under 5 years old. The trend of diphtheria suspicion was increasing in adulthood. Given the target age for ORI, the majority (92\%) were less than 19 years old and thus not targetted to receive ORI. Most parents of the suspects did not know their child's immunization status, while other said their children had never been immunized. Only $6.7 \%$ of the suspects had documentary evidence such as growth chart cards. It suggests that most suspects had incomplete immunization, thus increasing the risk of susceptibility to diphtheria. The use of antibody titers tend to be higher because of better immunization intervals. Children should be immunized with diphtheria (in 0-12 months) and with booster (in 18 to 24 months) and BIAS (at grade 1 and 2 of elementary schools).

These results are consistent with Lubis's (2005) study, which states that children who received DPT immunization once showed a negative Schick test result of $72.73 \%$. Further, twice immunization could result in a negative Schick test result of $83.84 \%$ and 3 times immunizations showed a perfect negative Schick test result. It means the more complete the immunization, the better the immunization status.

Moreover, this study reports $24 \%$ of the suspects had never been immunized, the majority of suspects (43\%) had complete immunization status according to information from their parents (no documented evidence). Whereas the percentage of suspects with complete immunization status who had growth chart cards was only $7 \%$. This study further reveals nearly half of the suspects without immunization records were aged $>10$ years. While all suspects who had immunization records were less than 5 years old (toddlers). From these findings, immunization records and reporting system are required.

Furthermore, this study reports most of the suspects had problems with immunization due to incomplete immunization, undetected immunization status, and absence of immunization. These findings are relevant with other studies which find the relationship between diphtheria and immunization status. According to Utami (2010), incomplete immunization status could affect diphtheria transmission and put people at 3.9 times greater risks for contracting diphtheria compared with complete immunization status. Further, Widoyono (2011) explains the mortality rate in children without immunization is four times greater than children who are immunized.

\section{Suspects' characteristics based on symptoms}

According to its etiology, diphtheria is a very contagious disease caused by Corynebacterium diphtheria. It causes symptoms and signs such as fever at $38^{\circ} \mathrm{C}$, bleeding and painful swallowing due to grayish-white pseudomembranes or 
membranes in the throat, enlargement of the neck lymph nodes, and swollen soft neck tissue so-called the bull neck. Some other symptoms also inclde shortness of breath and snoring sound.

In 2018, the main reason for DAT treatmentwas made by the expert team's recommendation due to pseudomembranous symptoms. All suspects with these symptoms received DAT treatment. While other symptoms included epistaxis (3.3\%), bull neck (31.7\%), and stridor (36.7\%).

\section{Suspects' characteristics based on DAT status}

Doctors diagnosed diphtheria based on symptoms and clinical condition. Diphtheria treatment begins by distributing DAT and antibiotics to the suspects without laboratory results or swab results. DAT dose ranging between 20,000-100,000 IU was determined empirically based on disease severity and duration of disease, and suspects' weight ( Indonesian Ministry of Health, 2017).

The number of suspects recommended for DAT treatment was 19 people $(32 \%)$, who received 760,000 IU of DAT dose. The majority (63\%) recommended for DAT received 40,000 IU of DAT dose. The total number of DAT doses was 760,00 IU or on average 4 vials (@ 10,000 IU). The use of "controlled" DAT ould save 1,640,000 IU of DAT dose. If converted to 41 suspects, it would be formulates as 41 suspects $\mathrm{x} 4$ vials $=164$ vials $x$ Rp. 2,200,000 = IDR 360,800,000.

Based on response of actions, this study finds the faster the suspect was referred to a health service facility (a primary healthcare center and hospital), the less possible they would receive ADT treatment. There were $23 \%$ suspects with disease duration of 1-3 days (before being referred to a health service facility) who received DAT. Most suspects (56\%) had disease duration of 4-6 days. The success rate of treatment was $100 \%$ (no deaths), and all suspects were treated in less than 24 hours according to the standard.

\section{sSuspects' characteristics based on DAT treatment and results of laboratory tests}

Based on the results of laboratory tests, of the 60 suspects, there were 3 suspects with positive mythic toxicity. One of them was 16 years old, and two others were 22 years old. Two suspects $(67 \%)$ received DAT, and one suspect $(33 \%)$ did not receive DAT recommendation.

KA, 16 years old, Pasirian, never immunized, received ORI in the first round; WK, 22 years old, Pasirian, never immunized, received ORI in the first round; AN, 22 years old, Kunir, never immunized, did not receive ORI.

This study reports most adult suspects were positive diphtheria. Immunizationwere given to these suspects by considering their body immune. Besides, there were three suspects that had never had routine immunization. Kartono's research (2007) finds that the main factor that causes diphtheria was incomplete DPT/DT immunization which contributed to 46,403 times greater risk of diphtheria in children.

Two of three suspects were still students. This suggests that diphtheria transmission was associated with environmental aspects.

\section{Outbreak response immunization during diphtheria outbreaks in Lumajang district in 2018}

The Letter of East Java Governor assigned the Regent/Mayor on $8^{\text {th }}$ January 2017 Number: 460/69/012.4/2018 to immedeiately announce diphtheria outbreaks. Such immediate announcement aimed to anticipate spikes and disease transmission. During the outbreaks, an outbreak response immunization (ORI) program was carried out by referring to the Decree of the Regent of Lumajang Number: 188.45/16/427.12/2018 concerning diphtheria outbreaks and outbreak response immunization (ORI) program in Lumajang district.

The district had achieved the minimum target of ORI coverage at $90 \%$. 
However, several primary healthcare centers did not reach the minimum target. The lowest ORI coverage occurred to 12 primary healthcare cetners in the first ORI round.

The ORI coverage was not directly proportional to the number of suspects in each working area.

Based on the findings, the number of suspects would be more dominantly influenced by the population density compared to the ORI coverage. Diseases transmit easily through direct contact in high population densities such as urban areas (Notoatmojo, 2007; Achmadi, 2005).

\section{CONCLUSION}

The case report concludes during the diphtheria outbreaks in 2018, there were 60 suspects who were mostly 19 years old and became the target for ORI treatment. Only few suspected people had positive toxic oxygenic categories. All positive suspects had no routine immunization records. The shift to non-targetted age for ORI treatment increased after the third round. Besides, the treatment success rate was perfect and resulted in zero deaths. There were 19 suspects (32\%) who received DAT recommendation with 760,000 IU of DAT dose. Furthermore, the use of "controlled" DAT could save 1,640,000 IU.

Immunization records and report must always be improved, for example through growth chart books, maternal and child health books, and infant and toddler cohorts. Besides, the provincial government should supply more DAT stocks to reinfore response towards diphtheri treatment.

\section{REFERENCE}

Lumajang District Health Office, 2018, Laporan Kejadian Luar Biasa (KLB) Difteri dan Outbrek Response Immunization (ORI)
Kabupaen Lumajang Tahun 2018, Dinkes Lumajang

Regulation of the Minister of Health Nomor 1501 tahun 2010 tentang Jenis Penyakit Menular Tertentu yang Dapat Menimbulkan Wabah dan Upaya Penanggulangan.

Indonesian Ministry of Health, 2017. Pedoman Pencegahan dan Pengendalian Difteri, Direktorat Surveilans dan Karantina Kesehatan Direktorat Pencegahan dan Pengendalian Penyakit

Decree of the Regent of Lumajang Nomor 188.45/ 16/427.12/2018 tentang keadaan kejadian luar biasa difteri (KLB difteri)

Decree of the Regent of Lumajang Nomor : 188.45/ 17/427.12 /2018 Tentang Pokja Out Break Response Immunization (ORI) Difteri Kab. Lumajang

Kartono B, Purwana, dan Djaja. 2008. Hubungan Lingkungan Rumah dengan Kejadian Luar Biasa (KLB) difteri di Kabupaten Tasikmalaya (2005-2006) dan Garut Januari 2007 Jawa Barat. https://doi.org/10.21109/kesmas.v2 i5.250

Lubis, B. 2005. Penelitian Status Imunisasi Terhadap Penyakit Difteri Dengan Schick Test pada Murid Sekolah Taman Kanak-kanak di Kotamadya Medan. e-Journal USU Repository.

SE Gubernur Jatim kepada Bupati/Walikota, Nomor 460/69/012.4/2018 tanggal 8 Januari 2018 tentang Penetapan Situasi KLB Difteri di Jatim

Notoatmodjo, S. 2007. Promosi Kesehatan dan Ilmu Perilaku. Jakarta : Rineka Cipta

Utami, A.W., (2010). Faktor yang mempengaruhi kejadian penularan difteri di Kota Blitar Propinsi Jawa Timur, tesis. Fakultas Kesehatan Masyarakat

Universita 
368 The Indonesian Journal of Public Health, Vol 15, No 3 December 2020:356-368

Airlangga,Program Studi Ilmu

Kesehatan Masyarakat. 